\title{
Reduksi Stasiun Kerja Bottleneck pada Produksi Pakaian Gamis dan Koko dengan Menggunakan Theory Of Constraints
}

\author{
Salma Salimah*, M. Dzikron \\ Prodi Teknik Industri, Fakultas Teknik, Universitas Islam Bandung, \\ Indonesia.
}

*salmasalimah19@gmail.com,mdzikron@gmail.com

\begin{abstract}
CV. X is a company that produces and sells robe and koko shirt. This company has problems in fulfilling customer orders and often experiences backorder problems. To solve this problem, use Theory Of Constraints. The stages used are identifying constraints, exploiting constraints, subordination of non-contraints, and constraints elevation. The results of the identification of constraints, it is thread scissors work stations and the entire process Quality Control (QC) work station, experienced capacity constraints or bottlenecks. At the constraints exploitation stage, a linear program calculation is carried out to determine the optimal amount of production for the robe and koko shirt. The results are the optimal number of robes according to the number of requests, while the optimal number of koko shirts is less than the number of requests. In the subordination non constraints is carried out by applying the Drum Buffer Rope method, which gives a time buffer, namely 3 hours of overtime at the thread scissors work station and 2 hours at the entire process QC work station. The suggestion of increasing working hours may not be successful if it is carried out in the long term, so it is continued at the constraints elevation by providing additional workforce of 3 operators at the thread scissors work station and 1 operator at the entire process QC work station. Proposals for improvements made at the subordination non constraints and constraints elevation stages are checked with linear program calculations and the result is that after repairs are made, customer demand can be fulfilled.
\end{abstract}

Keywords: Theory of Constraints, bottlenecks, capacity constraints

Abstrak. CV. X adalah perusahaan yang memproduksi dan menjual produk gamis dan baju koko. Perusahaan ini memiliki permasalahan dalam memenuhi pesanan pelanggan dan sering mengalami masalah backorder. Untuk mengatasi permasalahan ini, menggunakan Theory Of Constraints. Tahapan yang digunakan adalah mengidentifikasi constraints, mengeksploitasi constraints, subordinasi non-constraints, dan elevasi constraints. Hasil identifikasi constraints diperoleh stasiun kerja gunting benang dan stasiun kerja Quality Control $(\mathrm{QC})$ keseluruhan proses, mengalami kendala kapasitas atau bottleneck. Pada tahapan eksploitasi constraints dilakukan perhitungan program linier untuk mengetahui jumlah optimal produksi produk gamis dan baju koko. Hasilnya jumlah optimal gamis sesuai dengan jumlah permintaan, sedangkan jumlah optimal baju koko kurang dari jumlah permintaan. Pada tahapan subordinasi non constraint dilakukan dengan menerapkan metode Drum Buffer Rope, yaitu memberi time buffer berupa overtime sebanyak 3 jam pada stasiun kerja gunting benang dan 2 jam pada stasiun kerja QC keseluruhan proses. Usulan penambahan jam kerja ada kemungkinan tidak berhasil jika dilakukan dalam jangka panjang, sehingga dilanjutkan pada tahapan elevasi constraints dengan memberikan tambahan tenaga kerja sebanyak 3 operator pada stasiun kerja gunting benang dan 1 operator pada stasiun kerja QC keseluruhan proses. Usulan perbaikan yang dilakukan pada tahap subordinasi non constraints dan elevasi constraints diperiksa dengan perhitungan program linier dan menghasilkan bahwa setelah dilakukan perbaikan, permintaan pelanggan dapat terpenuhi.

Kata Kunci: Theory of Constraints, bottleneck, kendala kapasitas 


\section{A. Pendahuluan}

CV. X merupakan perusahaan yang memproduksi dan menjual pakaian gamis dan baju koko. Tahapan proses dari pembuatan busana muslim yaitu gudang bahan baku, pola, cutting, penjahitan, QC in line, gunting benang, pasang kancing, QC keseluruhan proses, setrika, QC final, dan packing. Perusahaan ini menerima pesanan dari pelanggan pada setiap bulannya. Jumlah pesanan tertinggi terjadi pada tahun 2019.

Permasalahan yang dihadapi perusahaan adalah ketidakmampuan dalam memenuhi jumlah pesanan pelanggan. Hal ini dapat mengakibatkan terjadinya backorder. Backorder merupakan kondisi yang tidak diinginkan oleh perusahaan dan pelanggan, karena jika terjadi backorder perusahaan mengalami penambahan biaya produksi dan terganggu jadwal produksi bulan berikutnya, sedangkan pelanggan mengalami keterlambatan dalam menerima order. Salah satu penyebab perusahaan tidak mampu memenuhi pesanan yaitu kekurangan kapasitas.

Tabel 1. Perbandingan Kapasitas Dibutuhkan dan Kapasitas Tersedia

\begin{tabular}{|c|c|c|r|r|}
\hline \multirow{2}{*}{ Stasiun Kerja } & \multicolumn{2}{|c|}{ Waktu Baku (menit) } & $\begin{array}{c}\text { Kapasitas yang } \\
\text { Dabutuhkan (menit) }\end{array}$ & $\begin{array}{c}\text { Kapasitas } \\
\text { Tersedia (menit) }\end{array}$ \\
\cline { 2 - 3 } & Gamis & Baju Koko & Dibut.120 \\
\hline QC in Line & 1,98 & 1,60 & $19.269,84$ & 21.12 \\
\hline Gunting Benang & 5,67 & 5,28 & $57.733,12$ & 42.240 \\
\hline Pasang Kancing & 1,80 & 2,18 & $20.221,36$ & 21.120 \\
\hline QC Keseluruhan Proses & 2,59 & 2,54 & $26.878,59$ & 21.120 \\
\hline Steam (Setrika) & 3,76 & 2,88 & $35.973,68$ & 42.240 \\
\hline
\end{tabular}

Tabel 1 menunjukkan bahwa stasiun kerja gunting benang dan QC keseluruhan proses memiliki kebutuhan kapasitas lebih besar daripada kapasitas yang tersedia, sehingga kedua stasiun kerja tersebut menjadi stasiun kerja bottleneck. Hal tersebut dapat menyebabkan perusahaan menjadi tidak mampu dalam memenuhi keinginan konsumen sehingga dapat mengurangi loyalitas konsumen pada perusahaan.

Berdasarkan latar belakang yang telah diuraikan, maka tujuan dari penelitian ini yaitu:

1. Mengetahui faktor penyebab permintaan produksi tidak terpenuhi.

2. Mengetahui stasiun kerja yang menjadi stasiun kerja bottleneck.

3. Mereduksi jumlah stasiun kerja yang mengalami bottleneck.

\section{B. Metodologi}

Theory of Constratints (TOC) merupakan suatu pendekatan khusus yang digunakan untuk mengelola kendala dalam melakukan perbaikan berkelanjutan. Konsep dasar Theory of Constratints berfokus pada tiga ukuran kinerja diantaranya adalah throughput, persediaan, dan biaya operasional (Hansen dan Mowen, 2007). Menurut Tersine (1994) Theory of Constratints merupakan suatu filosofi perbaikan berkelanjutan yang berfokus pada proses identifikasi dan pengelolaan kendala untuk mencapai tujuan organisasi.

Terdapat lima langkah dalam penerapan Theory of Constraints yaitu sebagai berikut (Goldratt, 1990):

1. Identifikasi Kendala pada Sistem

Melakukan identifikasi kendala adalah suatu hal yang penting dilakukan karena menentukan prioritas berdasarkan pengaruhnya. Kendala dapat berupa orang, material, mesin, tingkat permintaan ataupun hal yang bersifat manajerial.

2. Tentukan Cara Mengeksploitasi Kendala pada Sistem Mengelola kendala dapat dilakukan dengan mengetahui segala sesuatu yang berkaitan erat dengan non-kendala. Langkah ini dilakukan dengan tujuan untuk memperbaiki kendala dengan cara memanfaatkan kendala yang ada di lantai produksi.

3. Subordinasi non constraints

Langkah ini dilakukan agar seluruh bagian pada sistem yang dilihat non kendala dapat mendukung keefektifan dari aktivitas perbaikan bagian yang menjadi kendala, segala sumber daya harus disinkronisasikan agar dapat membantu dalam perbaikan throughput perusahaan. 
4. Elevasi Kendala Sistem

Langkah ini dilakukan apabila setelah memperbaiki kendala yang paling utama setelah mengikuti langkah pertama sampai langkah ketiga namun belum menemukan hasil, maka usaha perbaikan yang lebih keras perlu dilakukan, artinya perlu dilakukan penambahan kapasitas pada kendala tersebut.

5. Kembali ke Langkah 1 dan hindari Inersia

Bila sebelum dilakukan langkah keempat, kendala sudah dapat diatasi dengan baik, maka kembali ke tahapan pertama, karena ketika sudah berhasil mengatasi kendala yang paling lemah dalam sistem, maka bagian yang lain akan menjadi yang paling lemah (prinsip continuous improvement).

Kapasitas merupakan kemampuan aktual atau potensial untuk melakukan suatu aktivitas, dengan kata lain kapasitas adalah jumlah aktivitas atau kegiatan yang dapat dilakukan oleh perusahaan. Jumlah kapasitas yang diperlukan perusahaan dipengaruhi oleh tingkat kinerja yang diperlukan (Hansen dan Mowen, 2007). Kapasitas perusahaan sejalan dengan konsep daya saing yang dipengaruhi oleh kemampuan pengelolaan sumber daya dan pengendalian operasional untuk menghasilkan produk yang diterima oleh konsumen (Dzikron, dkk., 2020). Menurut Tersine (1994), sumber daya bottleneck merupakan sumber daya yang memiliki kemampuan sama atau kurang dari permintaan pada perusahaan.

Menurut Sutalaksana, Anggawisastra dan Tjakramadja (2006), teknik pengukuran waktu dibagi menjadi dua bagian yaitu secara langsung dan secara tidak langsung. Pengukuran waktu secara langsung merupakan suatu teknik pengukuran yang dilaksanakan secara langsung di tempat pekerjaan yang bersangkutan dijalankan, yang termasuk dalam cara ini adalah jam henti dan sampling pekerjaan.

Menurut Umble dan Srikanth (1990) Drum Buffer Rope merupakan suatu rencana produksi yang dapat dimanfaatkan untuk mengatasi kendala kritis dalam pabrik seperti permintaan pasar, kapasitas, dan keterbatasan material. Menurut Tarliah dan Dimyati (2016) programa linier merupakan perencanaan aktivitas-aktivitas untuk mendapatkan hasil yang optimum, dengan tujuan yang terbaik diantara semua alternatif fisibel. Programa linier digunakan untuk membantu menyelesaikan persoalan pengalokasian ketika seseorang harus memilih tingkat kegiatan-kegiatan tertentu yang saling bersaing untuk menggunakan sumber daya yang diperlukan untuk melakukan kegiatan tersebut.

Penelitian ini bertujuan untuk mereduksi jumlah stasiun kerja bottleneck agar perusahaan dapat memenuhi permintaan pesanan pelanggan. Hal tersebut dapat diselesaikan dengan menggunakan pendekatan Theory Of Constraints (TOC), dengan penerapan langkahlangkah dalam TOC, dan menggunakan metode programa linier serta metode Drum Buffer Rope. Penelitian ini dilakukan di lantai produksi pakaian gamis dan baju koko CV. X. Metode pengumpulan data yang dilakukan yaitu wawancara dan observasi. Data yang dikumpulkan adalah data jumlah pesanan produk, jumlah pengiriman produk, alur produksi, jumlah stasiun kerja, waktu proses stasiun kerja bagian finishing, upah karyawan, dan keuntungan setiap unit.

Pengolahan data dilakukan dengan melakukan uji keseragaman data, uji kecukupan data, kemudian menghitung waktu baku, selanjutnya dilakukan penerapan langkah-langkah TOC. Langkah pertama TOC identifikasi constraints dilakukan untuk mengetahui kendala yang menyebabkan stasiun kerja tidak mampu menghasilkan produk sesuai target. Langkah ini dapat mengetahui faktor penyebab permintaan produksi tidak terpenuhi dengan cara membandingkan antara kapasitas yang tersedia dengan kapasitas yang dibutuhkan. Langkah kedua TOC eksploitasi constraints dilakukan untuk memperbaiki sistem kerja agar menjadi lebih efektif dan efisien dengan cara mensiasati kendala yang ada. Langkah ini dilakukan menggunakan programa linier dengan Software WinQSB yang akan membantu perusahaan untuk menentukan jumlah optimal produksi yang sesuai dengan kapasitas yang tersedia. 
Langkah ketiga TOC subordinasi non constraints bertujuan untuk mendukung keefektifan dari perbaikan kendala dan mencegah bagian non kendala memperumit proses perbaikan. Langkah ini dilakukan dengan menggunakan metode Drum Buffer Rope yang dapat membantu dalam proses mereduksi jumlah stasiun kerja bottleneck karena dengan metode tersebut stasiun kerja bottleneck akan menjadi Drum dan diberi Buffer, kemudian dikomunikasikan (Rope) antara stasiun kerja yang menjadi Drum dengan stasiun kerja sebelumnya yang memasok produk pada stasiun kerja tersebut. Langkah keempat TOC elevasi constraints dilakukan jika perbaikan kendala yang telah dilakukan pada langkah pertama sampai dengan langkah ketiga belum berhasil. Langkah ini dilakukan untuk mereduksi jumlah stasiun kerja bottleneck dengan mengusulkan penambahan kapasitas berupa penambahan operator atau penambahan shift.

Alternatif perbaikan yang telah diusulkan menggunakan penerapan langkah-langkah TOC, selanjutnya akan diperiksa dengan programa linier menggunakan Software WinQSB. Pemeriksaan hasil perbaikan tersebut dilakukan untuk membuktikan apakah setelah dilakukan perbaikan, permintaan produksi menjadi terpenuhi, selain itu hasil programa linier akan menunjukkan jumlah throughput yang diperoleh jika permintaan produksi terpenuhi. Hasil pengolahan data yang telah dilakukan kemudian akan dianalisis untuk mengetahui bahwa permasalahan yang terjadi di perusahaan dapat diatasi dengan menggunakan usulan perbaikan yang tepat.

\section{Hasil dan Pembahasan}

\section{Perhitungan Waktu Baku}

Perhitungan waktu baku dilakukan untuk mengetahui waktu proses dari stasiun kerja dengan memperhatikan faktor penyesuaian dan faktor kelonggaran. Tabel rekapitulasi waktu baku adalah sebagai berikut:

Tabel 2. Rekapitulasi Waktu Baku

\begin{tabular}{|c|l|c|c|c|}
\hline Produk & \multicolumn{1}{|c|}{ Stasiun Kerja } & $\begin{array}{c}\text { WS } \\
\text { (menit) }\end{array}$ & $\begin{array}{c}\text { WN } \\
\text { (menit) }\end{array}$ & $\begin{array}{c}\text { WB } \\
\text { (menit) }\end{array}$ \\
\hline \multirow{5}{*}{ Gamis } & QC in Line & 1,56 & 1,63 & 1,98 \\
\cline { 2 - 5 } & Gunting Benang & 4,32 & 4,67 & 5,67 \\
\cline { 2 - 5 } & Pasang Kancing & 1,36 & 1,51 & 1,80 \\
\cline { 2 - 5 } & QC Keseluruhan Proses & 2,03 & 2,14 & 2,59 \\
\cline { 2 - 5 } & Setrika (Steam) & 2,83 & 3,14 & 3,76 \\
\hline \multirow{3}{*}{$\begin{array}{c}\text { Baju } \\
\text { Koko }\end{array}$} & QC in Line & 1,25 & 1,32 & 1,60 \\
\cline { 2 - 5 } & Gunting Benang & 4,03 & 4,35 & 5,28 \\
\cline { 2 - 5 } & Pasang Kancing & 1,65 & 1,83 & 2,18 \\
\cline { 2 - 5 } & QC Keseluruhan Proses & 1,99 & 2,09 & 2,54 \\
\cline { 2 - 5 } & Setrika (Steam) & 2,16 & 2,40 & 2,88 \\
\hline
\end{tabular}




\section{Tahapan Theory of Constraints}

Theory of Constraints memiliki lima tahapan dalam proses penerapannya yaitu identifikasi constraints, eksploitasi contraints, subordinasi non cosntraints, elevasi contraints, dan kembali ke tahap pertama. Penelitian ini akan membahas Theory of Constraints sampai tahap 4 yaitu elevasi contraints karena keterbatasan waktu pada penelitian.

\section{Identifikasi Constraints}

Tahapan identifikasi constraints dilakukan dengan membandingkan antara kapasitas yang dibutuhkan dengan kapasitas yang tersedia.

Tabel 3. Perbandingan Kapasitas Dibutuhkan dan kapasitas Tersedia

\begin{tabular}{|c|c|c|r|r|r|c|}
\hline \multirow{2}{*}{ Stasiun Kerja } & \multicolumn{2}{|c|}{ Waktu Baku (menit) } & Kapasitas yang & $\begin{array}{c}\text { Kapasitas } \\
\text { Dibutuhkan (menit) }\end{array}$ & $\begin{array}{c}\text { Persentase } \\
\text { Tersedia (menit) }\end{array}$ & Keterangan \\
\cline { 2 - 3 } Beban Kerja & Gamis & Baju Koko & Dibun & \\
\hline QC in Line & 1,98 & 1,60 & $19.269,84$ & 21.120 & $91,24 \%$ & Non-Bottleneck \\
\hline Gunting Benang & 5,67 & 5,28 & $57.733,12$ & 42.240 & $136,68 \%$ & Bottleneck \\
\hline Pasang Kancing & 1,80 & 2,18 & $20.221,36$ & 21.120 & $95,75 \%$ & Non-Bottleneck \\
\hline QC Keseluruhan Proses & 2,59 & 2,54 & $26.878,59$ & 21.120 & $127,27 \%$ & Bottleneck \\
\hline Steam (Setrika) & 3,76 & 2,88 & $35.973,68$ & 42.240 & $85,16 \%$ & Non-Bottleneck \\
\hline
\end{tabular}

Tabel 3 menunjukkan bahwa kapasitas yang dibutuhkan pada stasiun kerja gunting benang dan stasiun kerja Quality Control $(Q C)$ keseluruhan proses melebihi kapasitas yang tersedia, sehingga persentase beban kerja pada kedua stasiun kerja tersebut melebihi $100 \%$, dan kedua stasiun kerja tersebut menjadi stasiun kerja bottleneck.

\section{Eksploitasi Constraints}

Tahapan eksploitasi constraints dilakukan dengan metode programa linier menggunakan Software Win QSB. Tahapan ini dilakukan untuk mengetahui jumlah masing-masing produk yang optimal untuk diproduksi agar sesuai dengan kapasitas atau sumber daya yang tersedia. Hasil perhitungan programa linier menggunakan Software Win QSB ditunjukkan pada Tabel 4. Tabel 4 menunjukkan jumlah optimal produksi gamis 6.698 unit dan baju koko 808 unit, dengan perolehan throughput sebesar Rp 221.121.500.

Tabel 4. Hasil Perhitungan Programa Linier dengan Software Win QSB

\begin{tabular}{|c|c|c|c|c|c|c|c|c|}
\hline & 11:25:13 & & Monday & December & 21 & 2020 & & \\
\hline & $\begin{array}{l}\text { Decision } \\
\text { Variable }\end{array}$ & $\begin{array}{c}\text { Solution } \\
\text { Value }\end{array}$ & $\begin{array}{l}\text { Unit Cost or } \\
\text { Profit c[i] }\end{array}$ & $\begin{array}{c}\text { Total } \\
\text { Contribution }\end{array}$ & $\begin{array}{l}\text { Reduced } \\
\text { Cost }\end{array}$ & $\begin{array}{l}\text { Basis } \\
\text { Status }\end{array}$ & $\begin{array}{l}\text { Allowable } \\
\text { Min. c(i) }\end{array}$ & $\begin{array}{l}\text { Allowable } \\
\text { Max. c(i) }\end{array}$ \\
\hline 1 & $x 1$ & $6,698.0000$ & $30,000.0000$ & $200,940,000.0000$ & $\mathbf{0}$ & basic & $26,846.5900$ & $\mathbf{M}$ \\
\hline \multirow[t]{3}{*}{2} & $x 2$ & 807.2612 & $25,000.0000$ & $20,181,530.0000$ & $\mathbf{0}$ & basic & $\mathbf{0}$ & $27,936.5100$ \\
\hline & Objective & Function & [Max. $]=$ & $221,121,500.0000$ & & & & \\
\hline & Constraint & $\begin{array}{l}\text { Left Hand } \\
\text { Side }\end{array}$ & Direction & $\begin{array}{c}\text { Right Hand } \\
\text { Side }\end{array}$ & $\begin{array}{c}\text { Slack } \\
\text { or Surplus }\end{array}$ & $\begin{array}{c}\text { Shadow } \\
\text { Price }\end{array}$ & $\begin{array}{l}\text { Allowable } \\
\text { Min. RHS }\end{array}$ & $\begin{array}{l}\text { Allowable } \\
\text { Max. RHS }\end{array}$ \\
\hline 1 & C1 & $14,553.6600$ & $<=$ & $21,120.0000$ & $6,566.3420$ & 0 & $14,553.6600$ & $M$ \\
\hline 2 & $\mathrm{C} 2$ & $42,240.0000$ & $<=$ & $42,240.0000$ & $\mathbf{0}$ & $4,734.8480$ & $40,089.6600$ & $45,819.0400$ \\
\hline 3 & C3 & $13,816.2300$ & $<=$ & $21,120.0000$ & $7,303.7710$ & $\mathbf{0}$ & $13,816.2300$ & $M$ \\
\hline 4 & C4 & $19,398.2600$ & $<=$ & $21,120.0000$ & $1,721.7370$ & $\mathbf{0}$ & $19,398.2600$ & $\mathbf{M}$ \\
\hline 5 & C5 & $27,509.3900$ & $<=$ & $42,240.0000$ & $14,730.6100$ & $\mathbf{0}$ & $27,509.3900$ & $M$ \\
\hline 6 & C6 & $6,698.0000$ & $<=$ & $6,698.0000$ & 0 & $3,153.4100$ & $3,970.7090$ & $7,077.2490$ \\
\hline 7 & C7 & 807.2612 & $<=$ & $3,736.0000$ & $2,928.7390$ & 0 & 807.2612 & $M$ \\
\hline 8 & C8 & $6,698.0000$ & $>=$ & 400.0000 & $6,298.0000$ & 0 & $-M$ & $6,698.0000$ \\
\hline 9 & C9 & 807.2612 & $>=$ & 400.0000 & 407.2612 & $\mathbf{0}$ & $-H$ & 807.2612 \\
\hline
\end{tabular}




\section{Subordinasi Non Cosntraints}

Subordinasi non constraints dilakukan dengan menggunakan metode Drum Buffer Rope (DBR). Stasiun kerja yang menjadi stasiun kerja bottleneck yaitu stasiun kerja gunting benang dan stasiun kerja QC keseluruhan proses menjadi Drum, kemudian sebelum kedua stasiun kerja yang menjadi drum akan diberi buffer berupa time buffer. Time buffer pada stasiun kerja bottleneck yaitu penambahan waktu overtime selama 3 jam per hari pada stasiun kerja gunting benang dan 2 jam per hari pada stasiun kerja QC keseluruhan proses. Kemudian gudang bahan baku, selaku stasiun kerja yang memasok produk akan terhubung oleh rope dengan stasiun kerja yang menjadi drum.

Tabel 5. Perbandingan kapasitas setelah penerapan DBR

\begin{tabular}{|c|c|c|c|c|c|}
\hline \multirow{2}{*}{ Stasiun Kerja } & \multicolumn{2}{|c|}{ Waktu Baku (menit) } & \multirow{2}{*}{$\begin{array}{c}\text { Kapasitas yang } \\
\text { Dibutuhkan } \\
\text { (menit) }\end{array}$} & \multirow{2}{*}{$\begin{array}{c}\text { Kapasitas } \\
\text { Tersedia } \\
\text { (menit) }\end{array}$} & \multirow{2}{*}{$\begin{array}{l}\text { Persentase } \\
\text { Beban Kerja }\end{array}$} \\
\hline & Gamis & Baju Koko & & & \\
\hline QC in Line & 1,98 & 1,60 & $19.269,84$ & 21.120 & $91,24 \%$ \\
\hline Gunting Benang & 5,67 & 5,28 & $57.733,12$ & 59.520 & $97,00 \%$ \\
\hline Pasang Kancing & 1,80 & 2,18 & $20.221,36$ & 21.120 & $95,75 \%$ \\
\hline QC Keseluruhan Proses & 2,59 & 2,54 & $26.878,59$ & 26.880 & $99,99 \%$ \\
\hline Steam (Setrika) & 3,76 & 2,88 & $35.973,68$ & 42.240 & $85,16 \%$ \\
\hline
\end{tabular}

Tabel 5 menunjukkan bahwa setelah perbaikan dengan menerapkan metode Drum Buffer Rope, stasiun kerja gunting benang dan stasiun kerja QC keseluruhan proses mengalami peningkatan kapasitas, dan persentase beban kerja kurang dari $100 \%$.

\section{Elevasi Constraints}

Tahapan elevasi constraints dilakukan jika tahapan satu sampai tahapan tiga belum berhasil menyelesaikan masalah, sehingga perlu dilakukan tahapan ini. Penerapan overtime seperti yang dilakukan pada tahap subordinasi non constraints dapat menimbulkan kemungkinan tidak berhasil, karena waktu lembur yang dibutuhkan pada stasiun kerja bottleneck yaitu 3 jam pada stasiun kerja gunting benang dan 2 jam pada stasiun kerja QC keseluruhan proses yang perlu dilakukan pada setiap hari kerja. Hal ini dapat memberatkan operator jika dilakukan dalam waktu jangka panjang, oleh karena itu diusulkan tahapan elevasi constraints untuk menambah kapasitas pada stasiun kerja yang menjadi kendala. Tahapan elevasi constraints dilakukan dengan memberi 2 alternatif.

- Alternatif pertama dilakukan penambahan operator pada stasiun kerja gunting benang sebanyak 3 orang, dan pada stasiun kerja QC keseluruhan proses sebanyak 1 orang.

Tabel 6. Perbandingan kapasitas setelah penambahan operator

\begin{tabular}{|c|c|c|c|c|c|}
\hline \multirow{2}{*}{ Stasiun Kerja } & \multicolumn{2}{|c|}{ Waktu Baku (menit) } & $\begin{array}{c}\text { Kapasitas yang } \\
\text { Dibutuhkan } \\
\text { (menit) }\end{array}$ & $\begin{array}{c}\text { Kapasitas } \\
\text { Tersedia } \\
\text { (menit) }\end{array}$ & $\begin{array}{c}\text { Persentase } \\
\text { Beban Kerja }\end{array}$ \\
\hline Qamis & Baju Koko & 1,60 & $19.269,84$ & 21.120 & $91,24 \%$ \\
\hline Gunting Benang & 1,98 & 1,60 & $57.733,12$ & 73.920 & $78,10 \%$ \\
\hline Pasang Kancing & 1,80 & 2,18 & $20.221,36$ & 21.120 & $95,75 \%$ \\
\hline QC Kesehuruhan Proses & 2,59 & 2,54 & $26.878,59$ & 31.680 & $84,84 \%$ \\
\hline Steam (Setrika) & 3,76 & 2,88 & $35.973,68$ & 42.240 & $85,16 \%$ \\
\hline
\end{tabular}

Tabel 6 menunjukkan bahwa setelah dilakukan penambahan operator, terjadi peningkatan kapasitas dan persentase beban kerja kurang dari $100 \%$. 
- Alternatif kedua dilakukan penambahan masing-masing 1 shift pada stasiun kerja gunting benang dan stasiun kerja QC keseluruhan proses.

Tabel 7. Perbandingan kapasitas setelah penambahan shift

\begin{tabular}{|c|c|c|c|c|c|}
\hline \multirow{2}{*}{ Stasiun Kerja } & \multicolumn{2}{|c|}{ Waktu Baku (menit) } & \multirow{2}{*}{\begin{tabular}{|c} 
Kapasitas yang \\
Dibutuhkan \\
(menit)
\end{tabular}} & \multirow{2}{*}{$\begin{array}{c}\text { Kapasitas } \\
\text { Tersedia } \\
\text { (menit) }\end{array}$} & \multirow{2}{*}{$\begin{array}{c}\text { Persentase } \\
\text { Beban Kerja }\end{array}$} \\
\hline & Gamis & Baju Koko & & & \\
\hline $\mathrm{QC}$ in Line & 1,98 & 1,60 & $19.269,84$ & 21.120 & $91,24 \%$ \\
\hline Gunting Benang & 5,67 & 5,28 & $57.733,12$ & 84.480 & $68,34 \%$ \\
\hline Pasang Kancing & 1,80 & 2,18 & $20.221,36$ & 21.120 & $95,75 \%$ \\
\hline QC Keseluruhan Proses & 2,59 & 2,54 & $26.878,59$ & 42.240 & $63,63 \%$ \\
\hline Steam (Setrika) & 3,76 & 2,88 & $35.973,68$ & 42.240 & $85,16 \%$ \\
\hline
\end{tabular}

Tabel 7 menunjukkan bahwa setelah dilakukan penambahan shift pada stasiun kerja gunting benang dan QC keseluruhan proses, terjadi peningkatan kapasitas dan persentase beban kerja kurang dari $100 \%$.

Biaya yang harus dikeluarkan pada kedua alternatif tersebut ditunjukkan pada Tabel 8 .

Tabel 8. Hasil Perhitungan Biaya

\begin{tabular}{|l|l|}
\hline \multicolumn{1}{|c|}{ Alternatif } & \multicolumn{1}{c|}{ Biaya yang dikeluarkan } \\
\hline 1). Penambahan Operator & $\mathrm{Rp} 4.700 .000$ \\
\hline 2). Penambahan Shift & $\mathrm{Rp} 7.050 .000$ \\
\hline
\end{tabular}

Hasil perhitungan biaya yang harus dikeluarkan pada masing-masing alternatif ditunjukkan bahwa biaya yang harus dikeluarkan untuk penambahan shift lebih mahal dibandingkan dengan melakukan penambahan operator, sehingga dipilih alternatif pertama yaitu penambahan operator.

\section{Diskusi Hasil}

Hasil penelitian tahapan pertama TOC identifikasi cosntraints menunjukkan stasiun kerja gunting benang dan stasiun kerja QC keseluruhan proses memiliki kapasitas yang dibutuhkan lebih besar dari kapasitas yang tersedia, sehingga kedua stasiun kerja tersebut merupakan stasiun kerja bottleneck. Tahapan kedua eksploitasi cosntraints dilakukan menggunakan programa linier Software Win QSB untuk menghitung jumlah optimal produksi gamis dan baju koko. Hasil perhitungan tertera pada Tabel 4 yang menunjukkan bahwa jumlah optimal gamis sesuai dengan jumlah permintaan, sedangkan jumlah optimal baju koko kurang dari jumlah permintaan sebenarnya. Tahapan ketiga subordinasi non cosntraints dilakukan dengan menggunakan metode Drum Buffer Rope dengan memberikan time buffer berupa overtime selama 3 jam pada stasiun kerja gunting benang dan 2 jam pada stasiun kerja QC keseluruhan proses.

Hasil perhitungan setelah penerapan DBR tertera pada Tabel 5 yang menunjukkan bahwa setelah dilakukan perbaikan, tidak ada stasiun kerja yang mengalami kekurangan kapasitas. Tahapan keempat elevasi constraints, dilakukan bila tahapan satu sampai tahapan tiga belum bisa menyelesaikan masalah, sehingga dilakukan penambahan kapasitas. Penerapan overtime yang dilakukan pada tahap subordinasi non constraints dapat menimbulkan kemungkinan tidak berhasil karena dapat memberatkan karyawan bila dilakukan dalam jangka panjang. Penambahan kapasitas pada tahapan ini dilakukan dengan memberi dua alternatif yaitu alternatif pertama penambahan 3 operator pada stasiun kerja gunting benang dan penambahan 1 operator pada stasiun kerja QC keseluruhan proses, sedangkan alternatif kedua yaitu penambahan masing-masing 1 shift pada stasiun kerja gunting benang dan stasiun kerja QC keseluruhan proses. Diantara kedua alternatif tersebut, dipilih alternatif pertama karena mengeluarkan biaya yang lebih sedikit. 


\section{Kesimpulan}

Berdasarkan hasil penelitian yang telah dilakukan, diperoleh kesimpulan sebagai berikut:

1. Hasil identifikasi menemukan faktor penyebab permintaan produksi tidak terpenuhi yaitu terdapat permasalahan terkait dengan kelancaran produksi berupa bottleneck pada beberapa stasiun kerja.

2. Stasiun kerja yang mengalami kendala pada kapasitas (stasiun kerja bottleneck) yaitu stasiun kerja gunting benang dan stasiun kerja QC keseluruhan proses. Stasiun kerja gunting benang memiliki kapasitas tersedia 42.240 menit, sedangkan kapasitas yang dibutuhkan 57.734 menit. Stasiun kerja QC keseluruhan proses memiliki kapasitas tersedia 21.120 menit, sedangkan kapasitas yang dibutuhkan 26.879 menit.

3. Perbaikan yang dilakukan pada tahapan pertama TOC identifikasi constraints ditemukan dua stasiun kerja mengalami bottleneck, tahapan kedua TOC eksploitasi constraints dilakukan dengan menyesuaikan jumlah penerimaan pesanan dengan jumlah optimal produksi berdasarkan perhitungan programa linier.

4. Perbaikan yang dilakukan pada tahapan ketiga TOC subordinasi non constraints yaitu penambahan jam kerja (overtime) pada stasiun kerja gunting benang selama 3 jam dan pada stasiun kerja QC keseluruhan proses selama 2 jam. Perbaikan yang dilakukan pada tahapan keempat TOC elevasi constraints yaitu penambahan 3 operator pada stasiun kerja gunting benang dan 1 operator pada stasiun kerja QC keseluruhan proses.

5. Berdasarkan hasil pemeriksaan setelah perbaikan dengan programa linier menggunakan software Win QSB diperoleh hasil bahwa setelah dilakukan perbaikan, perusahaan dapat memenuhi permintaan pelanggan.

\section{Acknowledge}

Peneliti mengucapkan terima kasih kepada Bapak Dr. M. Dzikron A.M., Ir., IPM dan Ibu Dr. Nita P. A. Hidayat, Ir., M.T selaku dosen pembimbing yang telah menyediakan waktu, tenaga, dan pikiran untuk memberikan bimbingan dalam penelitian. Peneliti juga mengucapkan terima kasih kepada pihak perusahaan CV. X yang telah banyak membantu dalam pengumpulan data yang diperlukan. 


\section{Daftar Pustaka}

[1] Dzikron, M., Primiana, I., Kaltum, U. dan Wibisono, D. (2020) 'Design of The Competitiveness Model in Leather Tanning Industry', Development Management, 18(2), pp. 1-8.

[2] Goldratt, E. (1990) What is This Thing Called Theory Of Constraints and How Should it be Implemented? Massachusetts: North River Press.

[3] Hansen, D. dan Mowen, M. (2007) Managerial Accounting. 8th edn. Ohio: Thomson Higher Education.

[4] Sutalaksana, I., Anggawisastra, R. dan Tjakramadja, J. (2006) Teknik Perancangan Sistem Kerja. Bandung: ITB.

[5] Tarliah, T. dan Dimyati, A. (2016) Operation Research Model-Model Pengambilan Keputusan. Bandung: Sinar Baru Algesindo.

[6] Tersine, R. J. (1994) Principles of Inventory and Materials Management. New Jersey: PTR Pretice-Hall, Inc.

[7] Umble, M. dan Srikanth, M. L. (1990) Synchronous Manufacturing - Principles For World-Class Excellence. Ohio: South-Western Publishing Co. 